\title{
THE
}

\section{HISTORICAL JOURNAL}

\author{
VOLUME XXIII \\ EDITORIAL COMMITTEE \\ Professor D. E. D. BEAles, Ph.D. \\ T. C. W. BLANNING, Ph.D. \\ J. P. T. BURY, LITT.D. \\ Profiessor W. O. CHADWICK, D.D., F.B.A. \\ Professor G. R. ELton, Litt. D., F.B.A. \\ Professor F. H. HINSLEY, M.A. \\ J. S. MORRILL, PH.D. \\ H. M. PELLING, LitT.D., F.B.A. \\ PROFESSOR Q. R. D. SKINNER, M.A. \\ Professor E. T. STOKES, Ph.D. \\ EDITORS \\ C. M. ANDREW, PH.D. \\ V. A. C. GATRELL, PH.D. \\ CAMBRIDGE UNIVERSITY PRESS \\ CA M B R I D G E \\ LONDON NEW YORK NEW ROCHELLE \\ MELBOURNE SYDNEY \\ 1980
}


PUBLISHED BY

THE PRESS SYNDICATE OF THE UNIVERSITY OF CAMBRIDGE

The Pitt Building, Trumpington Street, Cambridge CB2 IRP

32 East 57th Street, New York, NY 10022

(C) Cambridge University Press 1980

\author{
Printed in Great Britain \\ at the \\ University Press, Cambridge
}




\section{CONTENTS OF VOLUME XXIII}

(Page numbers are at the end of each entry)

\section{ARTICLES AND COMMUNICATIONS}

Wolsey's Foreign Policy: The Conferences at Calais and Bruges Reconsidered. By Peter Gwyn 755

The Tudor Commonwealth: Revising Thomas Cromwell. By J. A. Guy $68 \mathrm{I}$

Thomas Cromwell and Ireland, I 532-I540. By Steven G. Ellis

Bishop Gardiner, Machiavellian. By Peter Donaldson I

Sir Nicholas Bacon and the Elizabethan via media. By Patrick Collinson 255

Thomas Norton the parliament man: an Elizabethan M.P., 1559-1581. By M. A. R. Graves I 7

The Castilian Bankruptcy of I575. By A. W. Lovett 899

The Authorship and early reception of $A$ Conference about the next succession to the crown of England. By Peter Holmes 4 I5

Sir John Davies, the Ancient Constitution, and Civil Law. By Hans S. Pawlisch 689

Cromwell's Status and Pay in 1646-47. By Charles Hoover $\quad 703$

A General Theory of Party, Opposition and Government, I688-1832. By J. C. D. Clark 295

Anti-popery on the Welsh Marches in the Seventeenth Century. By Philip Jenkins 275

La République au Village in the Southern Massif-Central, 1789-1 799. By P. M. Jones 793

The Scottish Campaign against the Test Act, I 790-I 79 I. By G. M. Ditchfield 37

Politics and power: the Triumph of Jacobinism in Strasbourg, I 79 I-1 793. By Hugh Gough $\quad 327$

Mercantilism Revisited. By D. C. Coleman 773

The old European States-system: Gentz versus Hauterive. By Murray Forsyth $52 \mathrm{I}$

The House of Lords and Parliamentary Patronage in Great Britain, $1802-1832$. By James J. Sack 9 I 3

Emigration and the State, $1803^{-1} 842$ : the Nineteenth-Century Revolution in Government reconsidered. By Peter Dunkley 353

Some Aspects of Working-class Consciousness in Oldham, I830-1 842. By R. A. Sykes $\quad$ I $67^{\circ}$

A Backbencher on Parliamentary Reform, I831-1832. By Mark O'Neill and Ged Martin 539

The Abolition of Negro Slavery and British Parliamentary Politics 1 832-3. By Izhak Gross 63

Thomas Babington Macaulay and Frederick the Great. By Timothy C. F. Stunt $\quad 939$ 
Naval Hagiography and the Victorian Hero. By C. I. Hamilton $38 \mathrm{I}$

Disraeli's imperialism, I866-1868: a question of timing. By Freda Harcourt 87

Political Economy and the Response to Socialism in Britain, 1870-1914. By John W. Mason $\quad 5^{6} 5$

The Thiers Government and the Outbreak of Civil War in France, FebruaryApril 187 I. By Robert Tombs 813

The Freiheit Prosecutions, $188 \mathrm{I}-\mathbf{1}$ 882. By Bernard Porter 833

Capital and Capitalists in the Transvaal in the 18 gos and Igoos. By Donald Denoon II I

Repairing the entente cordiale and the new diplomacy. By Alan Cassels $\quad 133$ The date of Sir Robert Filmer's Patriarcha. By John M. Wallace 155

Welfare Legislation and the Unions during the First World War. By Noelle Whiteside 857

The Foreign Office and British Propaganda during the First World War. By Philip M. Taylor 875

New light on Loyd George's Mansion House Speech. By Timothy Boyle $43^{1}$

Pacifism and Politics in Britain, 1931-1935. By Michael Pugh 641

Imperialism in Decline? Tendencies in British Imperial policy between the wars. By John Darwin 657

Codebreaking in World Wars I and II : the major successes and failures, their causes and their effects. By David Kahn 617

State Purchase of the Liquor Trade in the First World War. By John Turner $5^{89}$

The 1945 General Election Reconsidered. By Henry Pelling

The British Press in the Suez Crisis. By Guillaume Parmentier

399

435

REVIEW ARTICLES

The Rules of the Game. By Tony Judt I8I

British Foreign Policy in the Nineteenth Century. By Bernard Porter $\quad$ I93

Political 'Theory and the 'Science of Society' in Victorian Britain. By Stefan Collini 203

Competitive co-operation: Anglo-American relations in World War Two. By

David Reynolds 233

The Foundations of Modern Political Thought. By M. Oakeshott

Parliament, Law and War in the 1620 s. By Derek Hirst 455

Recent Work in Modern German History. By Geoff Eley . 463

The Third French Republic. By D. R. Watson 481

The Historiography of the CIA. By R. Jeffreys-Jones $\quad 4^{89}$

The New Worlds Revisited: Some Recent Studies in the early History of

European Expansion. By G. V. S. Scammell 717

An Armistice in Civil War Studies. By Ronald Hutton $\quad 729$

More Tales from the Dark Continent. By Gwyn Prins 737 
'Now Wait for Last Year': Historians, the American Colonies and the Revolution. By D. H. Murdoch 949

Recent Publications on the French Revolution. By Hugh Gough 967

German Jacobins and the French Revolution. By T. C. W. Blanning $\quad 985$ Barrington Moore on Injustice. By Gareth Stedman-Jones 1003

Australia's History - 'Australian' or 'British'? By Ged Martin $\quad$ Ioog

Greece and the Gyprus Question. By Bill Wrigley Ior9

\section{BOOKS REVIEWED}

Evelyn Bernette Ackerman, Village on the Seine. Tradition and Change in Bonnières, I815-1914. By Tony Judt I8 I

Kenneth R. Andrews, The Spanish Caribbean: Trade and Plunder 1530-1630. By G. V. Scammell 717

K. R. Andrews, N. P. Canny and P. E. H. Hair (eds.), The Westward Enterprise: English Activities in Ireland, the Atlantic and America, $1480-1650$. By G. V. Scammell 7 I 7

Robert Ashton, The English Civil War. Conservation and Revolution I6o3-I649. By Ronald Hutton 729

Yehuda Bauer, The Holocaust in Historical Perspective. By Owen Chadwick 1023

Yehuda Bauer, The Jewish Emergence from Powerlessness. By Owen Chadwick 1023

J. J. Becker, 19I4: Comment les Français sont entrés dans la guerre; contribution à - l'étude de l'opinion publique printemps-êté 1914. By D. R. Watson $4^{81}$

John D. Bell, Peasants in Power. Alexander Stamboliski and the Bulgarian Agrarian National Union, I899-1923. By Tony Judt 181

Sylvain Bensidoun, L'agitation paysanne en Russie de I88I à 1902. By Tony Judt I $8 \mathrm{I}$

Douglas S. Blaufarb, The Counterinsurgency Era: U.S. Doctrine and Performance, I950 to the Present. By R. Jeffreys-Jones $\quad 489$

Richard Bonney, Political Change in France under Richelieu and Mazarin, 1624-1661. By M. Greengrass $25^{*}$

G. Bourdé, La Défaite du Front Populaire. By D. R. Watson $\quad 4^{8 \mathrm{I}}$

C. R. Boxer, The Church Militant in Iberian Expansion, 1440-1770. By G. V. Scammell

John Brewer and John Styles (eds.), An Ungovernable People: The English and their Law in the Seventeenth and Eighteenth Centuries. By J. A. Sharpe 747

Peter Brock, Polish Revolutionary Populism. A Study in Agrarian Socialist Thought from the 1830 s to the 1850 s. By Tony Judt $\quad 181$

John Browning and Richard Morton (eds.), 1776 . By D. H. Murdoch 949 J. C. Cairns (ed.), Contemporary France, Illusion, Conflict and Regeneration. By D. R. Watson $\quad 4^{81}$

Ray S. Cline, Secrets, Spies and Scholars: Blueprint of the Essential C.I.A. By R. Jeffreys-Jones $\quad 489$ 
William Colby and Peter Forbath, Honourable Men: My Life in the C.I.A. By R. Jeffreys-Jones $\quad 489$

F. Cooper, Plantation Slavery on the East Coast of Africa. By Gwyn Prim

William R. Corson, The Armies of Ignorance: The Rise of the American Intelligence Empire. By R. Jeffreys-Jones 489

Gordon A. Craig, Germany 1866-1945. By Geoff Eley $\quad 4^{6} 3$

Nancy Crawshaw, The Cyprus Revolt: An Account of the Struggle for Union with Greece. By Bill Wrigley ror 9

Noemie Emery, Washington: A Biography. By D. H. Murdoch 949

G. K. Fortescue (comp.); A. G. Broadhurst (rev.), French Revolutionary Collections in the British Library. By Hugh Gough $\quad 967$

Michael Freeden, The New Liberalism: An Ideology of Social Reform. By Stefan Collini 203

François Furet, Penser la Révolution française. By Hugh Gough $\quad 967$

François Gendron, La Jeunesse dorée. Episodes de la Révolution française. By Hugh Gough $\quad 967$

Gerald S. Graham, The China Station. War and Diplomacy $1830-1860$. By Bernard Porter $\quad 193$

Marcel Garand and Romuald Szramkiewicz, La Révolution française et la famille. By Hugh Gough $\quad 9^{6} 7$

Samuel B. Griffith II, In Defence of the Public Liberty: Britain, America, and the Struggle for Independence - From 1760 to the Surrender at Yorktown in 1781. By D. H. Murdoch 349

Tony Griffiths, Contempory Australia By Ged Martin $\quad$ Ioog

Willibald Gutsche (ed.), Herrschaftsmethoden des deutschen Imperialismus $1897^{-98}$ bis rgr7. By Geoff Eley $\quad 463$

Hellmut G. Haasis, Bibliographic zur deutschen linksrheinischen Revolutionsbewegung in den Jahren 1792/1793. By T. C. W. Blanning 985

Alex Hall, Scandal, Sensation and Social Democracy. The SPD Press and Wilhelmine Germany I8go-1914. By Geoff Eley 463

A. Hastings, A History of African Christianity, 1950-1975. By Gwyn Prins 737

Ernst Hinrichs, Eberhard Schmitt and Rudolf Vierhaus (hrsg.), Vom Ancien Régime zur Französischen Revolution: Forschungen und Perspektiven. By Hugh Gough $\quad 967$

F. H. Hinsley (ed.), British Foreign Policy under Sir Edward Grey. By Bernard Porter I93

David W. Howell, Land People in Nineteenth-Century Wales. By David Cannadine 247

Heir z Hürten and Georg Meyer (eds.), Adjutant im preußischen Kriegsministerium Juni 1918-Oktober 1919. Aufzeichnungen des Hauptmanns Gustav Böhm. By Geoff Eley $\quad 463$

J. Iliffe, A Modern History of Tanganyika. By Gwyn Prins 737

K. S. Inglis, The Australian Colonists. An Exploration of Social History $1788-1870$. By Ged Martin $\quad$ Ioog 
Edward Ingram, The Beginning of the Great Game in Asia I828-1834. By Bernard Porter I 93

J. R. Jacob, Robert Boyle and the English Revolution. By Ronald Hutton 729

Tony Judt, Socialism in Provence, I87I-1914: a Study in the Origins of the Modern French Left. By R. D. Anderson $75^{\text {I }}$

Michael Kammen, A Season of Youth; The American Revolution and the Historical Imagination. By D. H. Murdoch

Temma Kaplan, Anarchists of Andalusia, I868-1903. By Tony Judt ${ }_{\text {I }} 8$

Christopher Kent, Brains and Numbers: Elitism, Comtism and Democracy in Mid-Victorian England. By Stefan Collini 203

Martin Kitchen, The Political Economy of Germany 1815-1914. By Geoff Eley $4^{63}$

Axel Kuhn, Jakobiner im Rheinland: Der Kölner konstitutionelle Zirkel von 1798. By T. C. W. Blanning $\quad 9^{8} 5$

Marjoire Lamberti, Jewish Activism in Imperial Germany. The Struggle for Civil Equality. By Geoff Eley $\quad 46_{3}$

Joseph P. Lash, Roosevelt and Churchill, 1939-194I: the Partnership that saved the West. By David Reynolds 233

John A. Leopold, Alfred Hugenberg. The Radical Nationalist Campaign against the Weimar Republic. By Geoff Eley $\quad 4_{3} 6_{3}$

James R. Leutze, Bargaining for Supremacy: Anglo-American Naval Collaboration, 1937-194I. By David Reynolds 233

Herbert Leventhal, In the Shadow of the Enlightenment: Occultism and Renaissance Science in Eighteenth-Century America. By D. H. Murdoch 949

Gwynne Lewis, The Second Vendée: the Continuity of Counter-Revolution in the Department of the Gard, $1789-18{ }_{15}$. By Hugh Gough $\quad 967$

David R. Lipton, Ernst Cassiver, The Dilemma of a Liberal Intellectual in Germany 1914-33. By Geoff Eley $\quad 463$

Jack Lively and John Rees (eds.), Utilitarian Logic and Politics: James Mill's 'Essay on Government', Macaulay's Critique and the Ensuing Debate. By Stefan Collini 203

Wm. Roger Louis, Imperialism at Bay, 194I-1945: The United States and the Decolonization of the British Empire. By David Reynolds 233

Hans-Ulrich Ludewig, Arbeiterbewegung und Aufstand. Eine Untersuchung zum Verhalten der Arbeiterparteien in den Aufstandsbewegungen der frühen Weimarer Republik 1920-1923. By Geoff Eley 463

Martyn Lyons, Revolution in Toulouse: an essay on Provincial Terrorism. By Hugh Gough $\quad 967$

William H. McNeill, The Metamorphosis of Greece since World War II. By Bill Wrigley г 19

W. F. Mandle, Going It Alone. Australia's National Identity in the Twentieth Century.

By Ged Martin I $\quad 009$

Charles Ronald Middleton, The Administration of British Foreign Policy $1782-1846$. By Bernard Porter $\quad 193$ 
T. B. Millar, Australia in Peace and War. External Relations 1788-1977. By Ged Martin $\quad$ loog

Richard Millman, Britain and the Eastern Question 1875-1878. By Bernard Porter 193

Barrington Moore, Jr, Injustice: The Social Bases of Obedience and Revalt. By Gareth Stedman-Jones 1003

S. E. Morison, The Great Explorers. by G. V. Scammell 717

John F. Morley, Vatican Diplomacy and The Jews during the Holocaust. By Owen Chadwick ro23

Olga A. Narkiewicz, The Green Flag. Polish Populist Politics, 1867-1970. By Tony Judt I8I

J. H. Parry, The Discovery of South America. By G. V. Scammell 717

Abraham J. Peck, Radicals and Reactionaries: The Crisis of Conservatism in Wilhelmine Germany. By Geoff Eley $\quad 4^{6} 3$

M. Perham, East African Journey: Kenya and Tanganyika, 1929-30. By Gwyn Prins 737

Donald Pernington and Keith Thomas (eds.), Puritans and Revolutionaries. Essays in Seventeenth Century History Presented to Christopher Hill. By Ronald Hutton 729

Maureen Perrie, The Agrarian Policy of the Russian Socialist-Revolutionary Party from its Origins through the Revolution of 1905-1907. By Tony Judt $\quad$ I 8 I

Perspectives in American History. By D. H. Murdoch 949

David Atlee Phillips, The Night Watch. By R. Jeffreys-Jones $\quad 4^{89}$

J. R. Pole, The Pursuit of Equality in American History. By Marcus Cunliffe 749

Jeremy D. Popkin, The Right-Wing Press in France, I792-180o. By Hugh Gough $\quad 967$

H. C. Porter, The Inconstant Savage. England and the North American Indian, 1500-1660. By G. V. Scammell

A. Prost, Les Anciens Combattants et la Société Française 1914-1939. By D. R. Watson $\quad 481$

R. Rémond and J. Bourdin (Eds.), Edouard Daladier, Chef de Gouvernement, Avril 1938, Septembre 1939 and La France et Les Français en 1938-1939. By D. R. Watson $\quad 4^{8} \mathrm{I}$

John C. G. Röhl, Philipp Eulenburgs Politische Korresponenz. Band II. Im Brennpunkt der Regierungskrise $1892-1895$. By Geoff Eley 463

Harry A. Rositzke, The CIA's Secret Operations: Espionage, Counterespionage, and Covert Action. By R. Jeffreys-Jones $\quad 489$

Conrad Russell, Parliament and English politics, $1621-1629$. By Derek Hirst 455

Inge Saatmann, Parlament, Rüstung und Armee in Frankreich, 1914-1918. By D. Stevenson 249

Halil Ibrahim Salih, Cyprus: The Impact of Diverse Nationalism on a State. By Bill Wrigley Io 9

Keith A. P. Sandiford, Great Britain and The Schleswig-Holstein Question 1848 64: 
a study in diplomacy, politics, and public opinion. By Bernard Porter I 93

Heinrich Scheel (ed.), Die Mainzer Republik. Protokolle des Jakobinerklubs, 5 vols. By T. C. W. Blanning $\quad 985$

J. B. Schneewind, Sidgwick's Ethics and Victorian Moral Philosophy. By Stefan Collini 203

George Schuster, Private Work and Public Causes: A Personal Record, $1881-1978$. By Duncan Wilson $75^{2}$

Kevin Sharpe (ed.), Faction and Parliament, Essays on Early Stuart History. By Ronald Hutton 729

Q. R. D. Skinner, The Foundations of Modern Political Thought. By M. Oakeshott 449

M. G. Smith, The Affairs of Daura: History and Change in a Hausa State, $1800-195^{8}$. By Gwyn Prins 737

M. H. Smith, The Writs of Assistance Case. By D. H. Murdoch 949

Albert Soboul (preface), Commission d' Histoire économique et sociale de la Révolution française, Mémoires et Documents XXXV: Colloque Albert Mathiez-Georges Lefebvre (3o Novembre-I Décembre 1974), Voies nouvelles pour l'histoire de la Révolution française. By Hugh Gough 967

Reba N. Soffer, Ethics and Society in England: The Revolution in the Social Sciences 1870-1914. By Stefan Collini 203

Bernd Sösemann, Das Ende der Weimarer Republik in der Kritik demokratischer Publizisten. By Geoff Eley $\quad 463$

Gavin Souter, Lion and Kangaroo. The Initiation of Australia I9or-I919. By Ged Martin I 009

O. H. K. Spate, The Spanish Lake. By G. V. Scammell 7 I 7

David Spring (ed.), European Landed Elites in the Nineteenth Century. By Tony Judt 18 I

Peter D. Stachura, The Weimar Era and Hitler 1918-1933. A Critical Bibliography. By Geoff Eley $\quad 463$

David E. Stannard, The Puritan Way of Death: A Study in Religion, Culture and Social Change. By D. H. Murdoch 949

Dirk Stegmann, Bernd-Jürgen Wendt and Peter-Christian Witt (eds.), Industrielle Gesellschaft und politisches System. Beiträge zur politischen Sozialgeschichte. Festschrift für Fritz Fischer. By Geoff Eley $4^{6} 6_{3}$

Zara S. Steiner, Britain and the Origins of the First World War. By Bernard Porter 193

Z. Sternhell, La Droite Revolutionnaire, 1885-1914, Les Origines Françaises du Fascisme. By D. R. Watson $48 \mathrm{r}$

Mark A. Stoler, The Politics of the Second Front: American Military Planning and Diplomacy in Coalition Warfare, 194I-1943. By David Reynolds 233

Philip Styles, Studies in Seventeenth Century West Midlands History. By Donald Hutton 729

Christopher Thorne, Allies of a Kind: The United States, Britain and the war against Japan, 1941-1945. By David Reynolds 233 
Alan Tulley, William Penn's Legacy: Politico and Social Structure in Provincial Pennsylvania, I726-I755. By D. H. Murdoch 949

Armand Van Dormael, Bretton Woods: Birth of a Monetary System. By David Reynolds 233

Louis-André Vigneras, The Discovery of South America and the Andalusian Voyages. By G. V. Scammell 717

David Walker, Dream and Disillusion. A Search for Australian Cultural Identity. By Ged Martin $\quad$ oog

Gary M. Walton and James F. Shepherd, The Economic Rise of Early America. By D. H. Murdoch 949

Russel Ward, The History of Australia. The Twentieth Century I9OI-1975. By Ged Martin 1009

Morton White, The Philosophy of the American Revolution. By D. H. Murdoch 949

Stephen D. White, Sir Edward Coke and 'the grievances of the commonwealth', I62I-I628. By Derek Hirst 455

David Wiltshire, The Social and Political Thought of Herbert Spencer. By Stefan Collini 203

J. Zeldin, France 1848-1945, vol. I : Ambition, Love and Politics; vol. 2 : Intellect, Taste and Anxiety. By D. R. Watson $\quad 48 \mathrm{I}$ 